\title{
Comparison of the Information on Financial Statements for Small and Micro Medium Enterprises Before and After Using Accounting Information System in Kupang City
}

\author{
Amram Rohi Bire*, Jermias Alang \\ State Polytechnic of Kupang \\ Kupang, Indonesia \\ *amram.rohi.bire@pnk.ac.id
}

\begin{abstract}
The current research, entitled "Comparison of the Quality of Information on Financial Statements for Small and Micro Medium Enterprises Before and After Using the Accounting Information System in Kupang City". The main problem formulation of this research is whether there is a difference in the quality of financial report information for small and medium enterprises before and after using the information system. Accounting in Kupang City"?. Meanwhile, the purpose of this study was to determine the differences in the quality of financial statement information for small and medium enterprises before and after using the accounting information system in Kupang City. The Data Analysis Technique method used first tested the research instrument (validity) and the normality test then the parametric statistical t-test (dependent sample test) using the SPSS 16 application. The results showed that the Shapiro Wilk normality test showed that the sig value of Shapiro Wilk before the Accounting Information System was 0.006 and after using the Accounting Information System it was 0.018 where $\mathbf{0 . 0 0 5}$, which means that the two data were normally distributed and could be continued with paired samples test. The results of the Paired Sample Test show the Sig value. (2tailed) of $0.000>0.05$, this shows that there is a significant difference in the quality of the financial statements of small and medium-sized businesses before and after using the Accounting Information System in Kupang City. The Small and Medium Enterprises in Kupang City can be applied to other Small and Micro Medium Enterprises in Kupang City. The results of this study are also in line with previous research on the application of accounting information systems.
\end{abstract}

Keywords-differences, quality, information, financial statements

\section{INTRODUCTION}

\section{A. Background}

The development of Information Technology is growing rapidly in various fields, including Small and Medium Enterprises and Micro. The quality of financial report information becomes the determinant for decision making that is fast, relevant (relevancy), more accurate (accuracy), and on time (timeliness), and the information presented can be accounted for by interested parties in business management, including MSMEs.

All business fields, including Small and Micro Enterprises, need this touch of information technology in the context of business effectiveness and efficiency. Even small and micro businesses today are very important to be equipped with information technology in their management for the speed, accuracy and accuracy of presenting financial information that leads to making the right decisions.

The Design of Accounting Information Systems in the presentation of Financial Statements for small and micro medium enterprises in Kupang City has been carried out by the various government and private agencies such as banks in business assistance for fostered partners as well as the role of Tri Dharma Perguruan Tinggi in this case including researchers and has even been implemented through previous programs and research.

Based on the results of the study, where the Accounting Information System can improve the quality of information on the financial statements of small and medium-sized enterprises and micro-enterprises in order to make the presentation of financial reports quick, accurate and relevant, it is necessary to apply the existing accounting information systems.

\section{B. Formulation of the Problem}

The problem in this research is as follow. Is there a difference in the quality of information on the financial statements of small and medium-sized enterprises before and after the application of the accounting information system in Kupang City? 


\section{Aim of the Research}

The purpose of this study was to determine the differences in the quality of information on financial statements of small and medium enterprises before and after the application of accounting information systems in Kupang City.

\section{LITERATURE REVIEW}

\section{A. Accounting Information System}

Krismiaji [1] states that the accounting system is a system that processes data and transactions to produce useful information for planning, controlling, and operating a business. To be able to produce the information required by decisionmakers, accounting information systems must carry out the following tasks; Collect transactions and other data and enter them into the system.

- Processing transaction data.

- Touring data for future use.

- Generate the necessary information by producing reports, or allow users to view the data stored in the computer themselves.

- Control the entire process in such a way that the information generated is accurate and reliable.

Related to the types of systems above, the accounting information system is a relatively closed type of system, because this system processes input into output by utilizing internal controls to limit environmental impacts. The input of an accounting information system is an economic transaction or event, for example, the sale of goods in cash, the sale of goods on credit, the payment of fees, and so on. These transactions are then processed by recording them in various reports. The output of the accounting information system is financial reports and management reports-figure 1 . The following clarifies the understanding of the accounting information system as a relatively closed system.

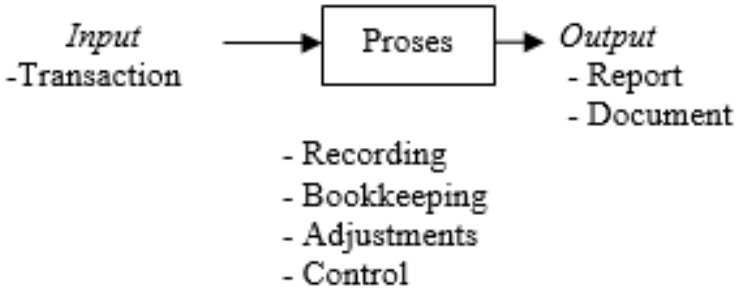

Fig. 1. Accounting process as a closed relative system.

In accounting information systems, internal supervision helps detect and prevent various environmental influences on the system. Examples of activities to reduce environmental impacts are footing (adding numbers in a column) and cross footing (comparisons between adding columns and adding rows).
1) Quality of information: O'brien [2] provides a summary of the attributes and quality of information into 3 (three) parts, namely:

a) Time dimension which includes:

- Timeliness means that information must be available when needed.

- Recency means that information must always be available when provided.

- Frequency means that information must be available as often as needed.

- Period means that information must be available for past, present and future periods.

b) Content dimensions which include:

- Accuracy means that information must be error-free.

- Relevance means that information must relate to the information needs of certain recipients for certain situations.

- Completeness means that all the information required must be available.

- Conciseness means that the required information is provided.

- Scope means that information can be both narrow and broad in scope, or for an internal or external focus.

- Performance means that information can show performance by measuring completed activities, progress achieved or accumulated resources.

c) Dimensions of the shape that includes:

- Clarity means that information must be available in a form that is easy to understand.

- Detailed means that information can be provided in a detailed and summarized form.

- Sequence means that information can be arranged in a predetermined order.

- Media means that information can be provided in the form of printed documents, video displays or other media.

\section{B. Financial Statement}

According to Hanafi and Halim [3], financial statements are a description of a company at a certain time (usually shown in an accounting period or cycle), which shows the financial condition that a company has achieved in a certain period. In other words, the financial report is a summary of a recording process, which is a summary of financial transactions that occurred during the financial year concerned. Complete financial statements usually include balance sheets, income statements, changes in financial position statements (which can be presented in various ways such as, for example, as cash flow 
statements or cash flow statements), notes and other reports and explanatory material that are an integral part of financial statements. According to IAI [4], the purpose of general purpose financial reports is to "provide information about the company's financial position, performance and cash flow that is useful for most users of the report in order to make economic decisions and show management accountability (stewardship) for the use of resources. Looking at the financial statements of a company will be reflected in the company's activities. Therefore, the company's financial statements are the result of an accounting process that can be used as a tool for communication and also as a means of measuring company performance. Financial reports provide the basis for investors to make decisions on whether to buy, hold, or sell their investments. As disclosed by IAI, financial statements are used in assessing a company's financial performance.

\section{Previous Research}

According to Sudadijaya's [5] research with the title Effect of Accounting Information System Implementation on Financial Report Quality (The study of PT. KERETA API INDONESIA (Persero) Bandung City concluded that partially the application of accounting information systems has an effect on the quality of financial statements $77.0 \%$ while the remaining $23 \%$ represents the influence of other factors from the two variables studied.

Resnawiyanti's [6] research results, under the title "Effect of Accounting Information Systems Implementation and Human Resources Coopetency on the Quality of Financial Statements of PT. POS INDONESIA (PERSERO)". The results of this study show partially the ERP-based Accounting Information System (AIS) application which uses the Financial Controlling (FIKO) module has a positive effect on the quality of financial reports and the competence of human resources has a positive effect on the quality of financial reports. Simultaneously, the ERP-based AIS that uses the Financial Controlling (FIKO) module has a positive effect on the quality of financial reports.

Meanwhile, according to Nurmalasari [7], conducted research entitled The Effect of Payroll Accounting Information Systems on the Quality of Financial Statements at PT. PEGADAIAN (PERSERO), the results of the study show that the Effect of Payroll Accounting Information Systems on the Quality of Financial Statements is equal to the coefficient of determination $(\mathrm{R})$ of $90.3 \%$. In comparison, $9.7 \%$ is influenced by other factors not included in this study.

\section{RESEARCH METHODS}

\section{A. The Scope of Research}

The research design used in which the object of research is Small and Medium Enterprises in Kupang City, which has implemented an Accounting Information System to present financial statements.

\section{B. Data Collection Technique}

To answer the activity objectives as mentioned above, primary data and secondary data were collected. Primary data collection is done by making observations, interviews and questionnaires.

\section{Data Analysis Techniques}

In analyzing the data, the researcher used the statistical parametric t-test method (dependent sample test) with the formula [8]:

$$
\mathrm{t}=\frac{\delta}{\operatorname{SD} \delta / \sqrt{\mathbf{n}}}
$$

Note:

$\delta=$ average deviation (the difference between samples before and after samples)

$\mathrm{SD} \delta=$ Standard deviation of $\delta$ (the difference between the sample before and the sample after)

$\mathrm{n}=$ the number of samples

$\mathrm{DF}=\mathrm{n}-1$

This data analysis technique was applied using the help of the SPSS 16 application.

\section{Population and Sample}

The population in this study were all MSMEs that have implemented Accounting Information Systems as many as 15 MSME business units in grilled fish business in Kupang City. Sampling was done by saturated sampling method, or all populations were sampled.

\section{E. Data Analysis Method}

The question items in the questionnaire were arranged on a Likert scale of 1-5. Following the objectives to be achieved, the data obtained were analyzed in stages:

- Compiling data, checking the completeness of the respondent's identity and filling out a questionnaire.

- Data tabulation is done to group data based on indicators.

- Data analysis, performed with the help of the SPSS parametric statistical comparison test (dependent sample test).

- Interpretation of Results; It interprets the output of SPSS so that conclusions can be drawn from the results of the study.

- Publications in accredited national/international journals. 


\section{RESULTS AND DISCUSSION}

\section{A. Shapiro Wilk Normality Test}

TABLE I. SHAPIRO WILK NORMALITY TEST

\begin{tabular}{|l|l|l|l|l|l|l|}
\hline \multicolumn{7}{|c|}{ Tests of Normality } \\
\hline & \multicolumn{1}{|c|}{ Kolmogorov-Smirnov } & \multicolumn{3}{|c|}{ Shapiro-Wilk } \\
\cline { 2 - 7 } & Statistic & $\boldsymbol{d f}$ & Sig. & Statistic & $\boldsymbol{d f}$ & Sig. \\
\hline Before AIS & .275 & 15 & .003 & .814 & 15 & .006 \\
\hline After AIS & .289 & 15 & .001 & .851 & 15 & .018 \\
\hline a. Lilliefors Significance Correction \\
\hline
\end{tabular}

Judging from the normality test of Shapiro Wilk in table 1, it can be seen that the sig value of Shapiro Wilk before the Accounting Information System is 0.006 and after using the Accounting Information System is 0.018. If a conclusion is drawn based on decision-making rules where if the Sig Shapiro
Wilk value is $>0.005$, then we can say the two sig data are> 0.005 , which means that the two sig data both before the Accounting Information System and After the Accounting Information System are normally distributed and can be continued with paired sample t-tests.

\section{B. Paired Sample T-test}

Paired Sample T-test is a test that seeks to determine whether there is a difference in the effect of treatment on the variable before and after treatment. In this study, the Paired Sample t-test was to determine whether there was a significant difference in the use of the Accounting Information System for Small and Medium Enterprises in Kupang City.

The following are the results of the Paired Sample t-test to examine whether the use of accounting information systems (before and after) in Small and Medium Enterprises in Kupang City (See Table 2):

TABLE II. PAIRED SAMPLE T-TEST

\begin{tabular}{|c|c|c|c|c|c|c|c|c|c|}
\hline \multicolumn{10}{|c|}{ Paired Samples Test } \\
\hline & & \multicolumn{5}{|c|}{ Paired Differences } & \multirow[b]{3}{*}{$\mathbf{T}$} & \multirow[b]{3}{*}{ df } & \multirow{3}{*}{$\begin{array}{l}\text { Sig. }(2 \\
\text { tailed })\end{array}$} \\
\hline & & \multirow[b]{2}{*}{ Mean } & \multirow{2}{*}{$\begin{array}{c}\text { Std. } \\
\text { Deviation }\end{array}$} & \multirow{2}{*}{$\begin{array}{l}\text { Std. Error } \\
\text { Mean }\end{array}$} & \multicolumn{2}{|c|}{$\begin{array}{l}\text { 95\% Confidence Interval of } \\
\text { the Difference }\end{array}$} & & & \\
\hline & & & & & Lower & Upper & & & \\
\hline Pair 1 & $\begin{array}{l}\text { Seb AIS - } \\
\text { Sesdh AIS }\end{array}$ & $-1.28000 \mathrm{E} 1$ & 2.14476 & .55377 & -13.98773 & -11.61227 & -23.114 & 14 & .000 \\
\hline
\end{tabular}

The Paired Sample Test shows the Sig. (2-tailed) of 0.000> 0.05 , this shows that there is a significant difference in the quality of the financial statements of small and medium enterprises before and after using the Accounting Information System in Kupang City. The Small and Medium Enterprises in Kupang City can be applied to other Small and Micro Medium Enterprises in Kupang City. The results of this study are also in line with previous research on the application of accounting information systems.

\section{CONCLUSION AND SUGGESTION}

\section{A. Conclusion}

Based on the analysis of the paired sample test, it can be seen that there are differences in the quality of financial reports before and after using the accounting information system. The Accounting Information System which is applied to Medium, Small and Micro Enterprises in Kupang City can be applied to other MSMEs in Kupang City.

\section{B. Suggestion}

Based on the results of the study, which shows that the Accounting Information System can improve the quality of information on financial statements of small and medium enterprises and micro enterprises, it is suggested that applying existing accounting information systems should be conducted.

\section{REFERENCES}

[1] Krismiaji, Sistem Informasi Akuntansi. Yogyakarta: Unit Penerbit dan Percetakan Sekolah Tinggi Ilmu Manajemen YKPN, 2010.

[2] J.A. O’Brien, Pengantar Sistem Informasi, Perspektif Bisnis dan Manajerial. Jakarta: Salemba Empat, 2005.

[3] M. Hanafi dan A. Halim, Analisis Laporan Keuangan. Yogyakarta: UPP STIM, 2010.

[4] Ikatan Akuntan Indonesia (IAI), Standar Profesional Akuntan Publik. Jakarta: Salemba Empat, 2017.

[5] Sudadijaya, "Pengaruh Penerapan Sistem Informasi Akuntansi Terhadap Kualitas Laporan Keuangan (Studi PT. Kereta Api Indonesia (Persero) Kota Bandung," 2017. [Online]. Retrieved from: http://repository.unpas.ac.id/id/eprint/31649

[6] L. Resnawiyanti, "Penelitian dengan judul Pengaruh Penerapan Sistem Informasi Akuntansi dan Koopetensi Sumber Daya Manusia Terhadap Kualitas Laporan Keuangan PT. POS Indonesia (PERSERO),” 2016. [Online]. Retrieved from: http://repository.widyatama.ac.id/xmlui/handle/123456789/8826

[7] Nurmalasari, "Penelitian dengan judul Pengaruh Sistem Informasi Akuntansi Penggajian Terhadap Kualitas Laporan Keuangan Pada PT. Pegadaian (PERSERO)," 2018. [Online]. Retrieved from: http://eprints.ummi.ac.id/id/eprint/266

[8] Sugiyono, Metode Penelitian Bisnis. Bandung: Alfabeta, 2012. 